$\begin{gathered}\text { Науковий вісник НЛтУ України } \\ \text { Scientific Bulletin of UNFU } \\ \text { http://nv.nltu.edu.ua }\end{gathered}$
$\begin{aligned} & \text { https://doi.org/10.15421/40280525 } \\ & \text { Article received 11.05.2018 p. } \\ & \text { Article accepted 41.05.2018 p. } \\ & \text { удк 629.3.01 }\end{aligned}$

С. В. Нємий, Я. С. Ярошинський

Національний університет "Львівська політехніка", м. Львів, Україна

\title{
ПРОБЛЕМИ ЯКОСТІ ІМПОРТОВАНИХ ВЖИВАНИХ АВТОМОБІЛІВ В АСПЕКТІ БЕЗПЕКИ ЕКСПЛУАТАЦІї
}

Кількісно оцінено модельний масив і якість імпортованих вживаних автомобілів. Результати дослідження будуть інформаційною базою для визначення: найбільш і найменш популярних в Україні (регіоні) моделей; рівня якості певних моделей імпортованих автомобілів; орієнтації сервісних служб (СТО) для освоєння технології технічного обслуговування і ремонту автомобілів, виходячи з обсягу найпоширеніших в Україні моделей імпортованих вживаних легкових автомобілів. За статистичним аналізом результатів сертифікації, проведеної ДП НДІ "СИСТЕМА", досліджено модельний масив імпортованих вживаних легкових автомобілів за моделями і їх характерними дефектами. Встановлено, що найбільш популярними в Україні є моделі легкових автомобілів фірми Renault і автомобільних фірм Німеччини. Оцінено рівень якості імпортованих вживаних автомобілів, серед яких найвищий рівень якості властивий переважно моделям німецьких виробників (Volkswagen, Mercedes-Benz, Audi, BMW) та іншим європейським і японським моделям (Skoda, Peugeot, Ford, Nissan, Toyota, Hyundai), прийнятий рівень якості яких перевищує 0,8. Назагал виділено порівняно високий рівень якості гальмівної системи автомобілів німецьких виробників - у середньому відносна кількість відмов становить 1,01 \%, порівняно з 1,63 \% для всієї вибірки. Під час планування діяльності сервісних фірм (СТО) доцільно надати перевагу технічному обслуговуванню автомобілів фірм Renault, Volkswagen, Opel, Mercedes-Benz, Skoda, Peugeot, Ford, Citroen.

Ключові слова: стандартизація; якість; сертифікація; ДП НДІ "СИСТЕМА"; невідповідності; вживані автомобілі; імпорт автомобілів.

Вступ. В останні десятиліття парк легкових автомобілів в Україні характеризується одним із найвищих у Європі за темпом зростання: 1990 р. - 1 млн 400 тис. шт.; 1999 р. - 3 млн 800 тис. шт.; 2004 р. - 5 млн 100 тис. шт.

У подальші роки парк легкових автомобілів в Україні щорічно збільшувався у середньому на 400 тис. шт. Щорічна місткість ринку легкових автомобілів в Україні змінюється в межах 280-350 тис. шт. (Yakovenco \& Krajnyc, 2005). На сьогодні зростання чисельності парку легкових автомобілів в Україні здебільшого здійснюється за рахунок імпорту вживаних автомобілів західноєвропейського й американського виробництва.

За даними асоціації "Укравтопром" (Import, 2017), упродовж трьох кварталів 2017 р. в Україну, в режимі імпорту, було ввезено 109,6 тис. легкових автомобілів. Порівняно $з$ аналогічним періодом минулого року, імпорт машин зріс на $92 \%$, а його митна вартість становила понад 1,5 млрд дол. 3 цієї суми майже 1,2 млрд дол. було витрачено на нові автомобілі, яких було завезено 60,5 тис. шт., а 346 млн дол. - на 49,1 тис. авто 3 пробігом.

Найбільшу кількість автомобілів в Україну було ввезено з країн $\mathrm{CC}-$ 69,6 тис. шт., що охопило понад
63 \% від загального обсягу імпорту легкових автомобілів за дев'ять місяців 2017 р. При цьому частка нових авто в євроімпорті була тільки $44 \%$, решта $56 \%$ припали на автомобілі, що були в експлуатації. Країною-лідером 3 постачання авто в Україну стала Німеччина, 3 якої ввезли 25 тис. машин: 5,5 тис. нових авто i 19,5 тис. 3 пробігом.

На другому місці імпорт 3 Японії - 13,9 тис. шт. (88,5 \% нові). Замикає трійку лідерів Франція, яка відправила в Україну 10 тис. легковиків. Основну кількість французького імпорту становили автомобілі 3 пробігом - 8,9 тис шт. За січень-жовтень 2017 р. обсяги митного оформлення вживаних авто на українських митницях зросли у 6 разів.

Технічний стан імпортованих вживаних автомобілів через експлуатаційну зношеність часом не відповідає показникам заводів-виробників і відповідним нормативним документам (національним стандартам) щодо гарантування безпеки експлуатації. Ця обставина потребує ефективного функціонування національної системи сертифікації з метою недопущення до експлуатації автомобілів із дефектами агрегатів і систем, що впливають на безпеку руху й екологічну безпеку, від чого, в принципі, залежить безпека життя громадян країни. Ре-

\section{Інформація про авторів:}

Нємий Степан Володимирович, канд. техн. наук, доцент, кафедра експлуатації та ремонту автомобільної техніки. Email: sniemyj@ukr.net

Ярошинський Ярослав Станіславович, магістрант, кафедра експлуатації та ремонту автомобільної техніки. Email: yaroslavyaroshynskyi@gmail.com

Цитування за ДСтУ: Нємий С. В., Ярошинський Я. С. Проблеми якості імпортованих вживаних автомобілів в аспекті безпеки експлуатації. Науковий вісник Нлту України. 2018, т. 28, № 5. С. 119-123.

Citation APA: Niemyi, S. V., \& Yaroshynskyi, Ya. S. (2018). The problems of quality of imported used cars in terms of safety of operation. Scientific Bulletin of UNFU, 28(5), 119-123. https://doi.org/10.15421/40280525 
гіональним органом із сертифікації $\epsilon$ державне підприємство, науково-дослідний інститут - ДП НДІ "СИСТЕМА", структурним підрозділом якого є випробувальна лабораторія, що оцінює технічний стан імпортованих вживаних автомобілів.

Аналіз відомих рішень і публікацій. У наявних публікаціях, наприклад у роботах (Yakovenco \& Krajnyc, 2005; Import, 2017; Sertyficat, 2015; Sredstwa, 2016), переважно наведено статистичні дані щодо імпорту зарубіжних легкових автомобілів та особливості законодавчої бази їх сертифікації в Україні. Системні результати дослідження, які б відображали кількісний склад модельного масиву імпортованих вживаних автомобілів, рівень їх відповідності (якості) та характерні невідповідності, в наукових публікаціях не трапляються.

Постановка завдання. Метою дослідження є кількісне оцінювання модельного масиву і якості імпортованих вживаних автомобілів. Результати дослідження будуть інформаційною базою для визначення: найбільш і найменш популярних в Україні (регіоні) моделей; рівня якості певних моделей імпортованих автомобілів; орієнтації сервісних служб (СТО) для освоєння технології технічного обслуговування і ремонту автомобілів, виходячи з обсягу найпоширеніших в Україні моделей імпортованих вживаних легкових автомобілів.
Основний матеріал. Наші дослідження базуються на даних регіонального органу із сертифікації, яким $\epsilon$ державне підприємство науково-дослідний інститут ДП НДІ "СИСТЕМА" (м. Львів). Структурними підрозділами цього підприємства проведено оцінювання відповідності колісних транспортних засобів (КТЗ), котрі були за рубежем у користуванні та після ввозу в Україну випробувані лабораторією випробувань колісних транспортних засобів (ВЛ-18) у період з 2016 по 2017 рр. загальною чисельністю 12784 одиниць КТЗ. 3 них за роками: у 2016 р. - 7430 КТЗ, а в 2017 р. (з 1 січня по 31 жовтня) - 5354 КТЗ.

Потенційну кількість заяв на сертифікацію у 2017 p. $N_{12}$ наведено до всього року:

$$
N_{12}=N_{10} \cdot 12 / 10=5354 \cdot 1,2=6425 \text { заяв, }
$$

де $N_{10}$ - фактична кількість заяв упродовж 10-ти місяців 2017 p.

Порівнюючи кількість заявок за два останні роки, бачимо, що кількість заявок за 2017 р. зменшилася на $16 \%$, порівняно із 2016 р. Причиною цього можуть бути як зниження купівельної спроможності населення, так і проблеми з вартістю митного оформлення ввезених автомобілів в Україну. Статистичні результати сертифікаційних випробувань, виконаних випробувальною лабораторією ДП НДІ "СИСТЕМА", впродовж 20162017 рр. наведено у табл. 1.

Табл. 1. Статистика імпорту вживаних автомобілів і відмов у сертифікації за 2016-2017 рр.

\begin{tabular}{|c|c|c|c|c|c|c|c|c|c|c|c|c|}
\hline \multirow[b]{2}{*}{$\begin{array}{l}\text { Виробник } \\
\text { автомобіля }\end{array}$} & \multirow[b]{2}{*}{$\begin{array}{c}\text { Кількість } \\
\text { поданих } \\
\text { заяв, } \mathrm{N}_{м i} \\
\text { шт. }\end{array}$} & \multirow[b]{2}{*}{$\begin{array}{c}\text { Кількість } \\
\text { відмов, } \\
\mathrm{N}_{\text {нi }} \text { шт. }\end{array}$} & \multicolumn{10}{|c|}{ Кількість характерних невідповідностей } \\
\hline & & & 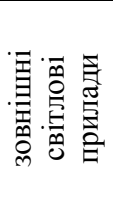 & 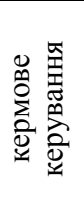 & 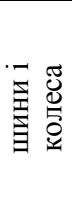 & 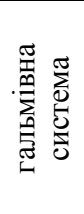 & 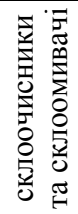 & 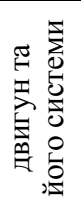 & 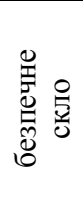 & 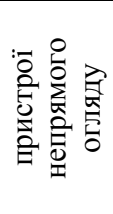 & 或 & 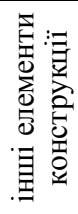 \\
\hline Renault & 3229 & 647 & 318 & 17 & 28 & 82 & 23 & 75 & 66 & 8 & 22 & 8 \\
\hline Volkswagen & 2150 & 384 & 157 & 7 & 8 & 25 & 7 & 23 & 86 & 17 & 24 & 30 \\
\hline Opel & 1422 & 288 & 106 & 7 & 13 & 13 & 6 & 39 & 82 & 7 & 9 & 6 \\
\hline Mercedes-Benz & 1054 & 190 & 57 & 3 & 6 & 12 & 11 & 22 & 55 & 2 & 5 & 17 \\
\hline Skoda & 1047 & 173 & 66 & 5 & 6 & 18 & 5 & 10 & 33 & 7 & 13 & 10 \\
\hline Peugeot & 641 & 125 & 43 & 3 & 5 & 14 & 10 & 24 & 19 & 3 & 2 & 2 \\
\hline Ford & 609 & 113 & 52 & 2 & 6 & 9 & 3 & 7 & 20 & 4 & 4 & 6 \\
\hline Citroen & 606 & 126 & 53 & 4 & 3 & 9 & 7 & 15 & 11 & 5 & 8 & 9 \\
\hline Audi & 338 & 52 & 18 & - & 2 & 4 & 1 & 3 & 12 & 2 & 2 & 8 \\
\hline Fiat & 330 & 80 & 25 & 3 & 2 & 7 & 4 & 12 & 9 & 4 & 5 & 9 \\
\hline BMW & 305 & 22 & 7 & 1 & 4 & 2 & - & 1 & 7 & - & - & - \\
\hline Nissan & 161 & 31 & 12 & - & 2 & 2 & 1 & 3 & 7 & - & 3 & 1 \\
\hline Toyota & 154 & 17 & 7 & - & 1 & - & - & - & 5 & 1 & 2 & 1 \\
\hline Hyundai & 96 & 15 & 5 & - & - & 2 & - & 1 & 5 & 1 & - & - \\
\hline Dacia & 90 & 19 & 3 & - & - & 2 & 1 & 1 & 5 & 1 & 3 & 2 \\
\hline Seat & 90 & 15 & 6 & - & - & 3 & 2 & 1 & 2 & 1 & - & - \\
\hline Chevrolet & 78 & 17 & 5 & 1 & 2 & 1 & - & 2 & 3 & 1 & - & 2 \\
\hline Volvo & 59 & 5 & 2 & - & - & - & - & - & 3 & - & - & - \\
\hline KIA & 43 & 7 & 4 & - & - & - & - & - & 3 & - & - & - \\
\hline Honda & 37 & 3 & 2 & - & - & - & - & - & 1 & - & - & - \\
\hline Mazda & 33 & 5 & 4 & - & - & - & - & - & 1 & - & - & - \\
\hline Mini & 29 & 6 & 5 & - & - & - & - & - & 1 & - & - & - \\
\hline Subaru & 21 & 6 & 3 & - & - & - & - & 3 & - & - & - & - \\
\hline Suzuki & 19 & 4 & 3 & - & - & 1 & - & - & - & - & - & - \\
\hline Mitsubishi & 19 & 4 & 1 & - & - & 1 & - & 1 & 1 & - & - & - \\
\hline Iveco & 16 & 3 & 2 & - & - & - & - & - & 1 & - & - & - \\
\hline Buick & 14 & 10 & 10 & - & - & - & - & - & - & - & - & - \\
\hline Land Rover & 14 & 2 & 1 & - & - & - & - & - & 1 & - & - & - \\
\hline Smart & 9 & 2 & - & - & - & 1 & - & 1 & - & - & - & - \\
\hline Alfa Romeo & 9 & 1 & - & - & - & - & 1 & - & 1 & - & - & - \\
\hline Infinity & 7 & 2 & 2 & - & - & - & - & - & - & - & - & - \\
\hline Всього & $\Sigma N=12784$ & 2364 & 986 & 53 & 88 & 209 & 82 & 245 & 438 & 61 & 102 & 111 \\
\hline
\end{tabular}

120 Науковий вісник НлтУ України, 2018, т. 28, № 5 Scientific Bulletin of UNFU, 2018, vol. 28, no 5 
3 даних табл. 1 можна зробити висновок про найпопулярніші в Україні (регіоні) моделі вживаних автомобілів. Якщо до найпопулярніших віднести моделі, чисельність яких перевищує 600 одиниць (різка межа між кількістю автомобілів Citroen i Audi), то до них відносимо моделі Renault, Volkswagen, Opel, Mercedes-Benz, Skoda, Peugeot, Ford, Citroen - усього 11 моделей.

До найменш популярних відносимо моделі, чисельність яких не перевищує 200 одиниць. Це 20 моделей, наведених у нижній частині табл. 1. Для подальших досліджень формуємо вибірку із сумарних даних сертифікаційних випробувань упродовж 2016 і 2017 рр. (сумарні дані за моделями згідно з табл. 1). Відносну (у \%) кількість ввезених вживаних автомобілів визначаємо за формулою

$$
N_{\text {вмi }}=\frac{N_{M i}}{\sum N} 100 \%,
$$

де: $N_{\text {вмі }}$ - відносна кількість ввезених вживаних автомобілів певної моделі; $N_{\text {мі }}$ - фактична кількість ввезених вживаних автомобілів певної моделі; $\Sigma N$ - загальна чи- сельність ввезених вживаних автомобілів (обсяг статистичної вибірки).

Рівень якості (відповідності) кожної моделі $\Delta N_{я}$ ввезених вживаних автомобілів визначаємо за формулою

$$
\Delta N_{\Omega}=\frac{N_{M i}-N_{H i}}{N_{M i}},
$$

де $N_{н i}$ - кількість автомобілів певної моделі з виявленими невідповідностями (відмова у сертифікації).

Відносну кількість відмов у системах і агрегатах кожної моделі автомобіля визначаємо за формулою

$$
\Delta N_{c a i}=\frac{N_{\text {нai }}}{N_{M i}} 100 \%,
$$

де: $\Delta N_{c a i}-$ відносна кількість кожного виду виявленої невідповідності автомобілів певної моделі; $N_{\text {наі }}-$ кількість автомобілів певної моделі із виявленою конкретною невідповідністю цього виду. Розрахунки за формулами (1) і (2) проводимо лише для моделей, чисельність яких перевищує 20 одиниць. Результати розрахунків

\begin{tabular}{|c|c|c|c|c|c|c|c|c|c|c|c|c|}
\hline \multirow[b]{2}{*}{$\begin{array}{l}\text { Виробник } \\
\text { автомобіля }\end{array}$} & \multirow[b]{2}{*}{\begin{tabular}{|c} 
Відносна \\
кількість \\
ввезених ав- \\
томобілів, \\
$N_{\text {вмі } \%}$
\end{tabular}} & \multirow[b]{2}{*}{$\begin{array}{c}\text { Рівень } \\
\text { якості } \\
\text { кожної } \\
\text { моделі } \\
\Delta N_{я}\end{array}$} & \multicolumn{10}{|c|}{ Відносна кількість відмов у системах і агрегатах $N_{\text {наi, }} \%$} \\
\hline & & & 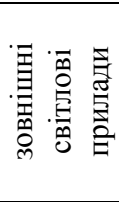 & 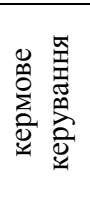 & 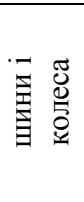 & 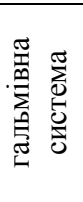 & 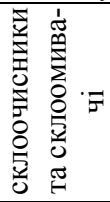 & 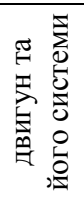 & 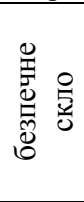 & 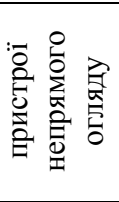 & 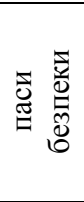 & 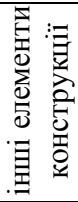 \\
\hline Renault & 25,26 & 0,800 & 9,85 & 0,53 & 0,87 & 2,54 & 0,71 & 2,32 & 2,04 & 0,25 & 0,68 & 0,71 \\
\hline Volkswagen & 16,81 & 0,821 & 7,3 & 0,33 & 0,37 & 1,16 & 0,33 & 1,07 & 4,0 & 0,79 & 1,17 & 1,39 \\
\hline Opel & 11,12 & 0,797 & 7,45 & 0,49 & 0,91 & 0,91 & 0,42 & 2,74 & 5,77 & 0,49 & 0,63 & 0,42 \\
\hline Mercedes-Benz & 8,24 & 0,820 & 5,4 & 0,28 & 0,57 & 1,14 & 1,04 & 2,09 & 5,2 & 0,19 & 0,47 & 1,61 \\
\hline Skoda & 8,20 & 0,835 & 6,3 & 0,48 & 0,57 & 1,72 & 0,48 & 0,96 & 3,15 & 0,67 & 1,24 & 0,96 \\
\hline \begin{tabular}{|l|} 
Peugeot \\
\end{tabular} & 5,00 & 0,805 & 6,7 & 0,47 & 0,78 & 2,18 & 1,56 & 3,74 & 2,96 & 0,47 & 0,31 & 0,31 \\
\hline Ford & 4,76 & 0,814 & 8,54 & 0,33 & 0,98 & 1,48 & 0,49 & 1,15 & 3,28 & 0,66 & 0,66 & 0,98 \\
\hline Citroen & 4,74 & 0,792 & 8,75 & 0,66 & 0,49 & 1,48 & 1,15 & 2,47 & 1,82 & 0,82 & 1,32 & 1,48 \\
\hline Audi & 2,64 & 0,846 & 5,32 & - & 0,59 & 1,18 & 0,30 & 0,89 & 3,55 & 0,59 & 0,59 & 2,37 \\
\hline Fiat & 2,58 & 0,758 & 7,58 & 0,91 & 0,61 & 2,12 & 1,21 & 3,64 & 2,73 & 1,21 & 1,51 & 2,73 \\
\hline BMW & 2,38 & 0,928 & 2,30 & 0,33 & 1,31 & 0,66 & - & 0,33 & 2,29 & - & - & - \\
\hline Nissan & 1,26 & 0,807 & 19,3 & - & 1,24 & 1,24 & 0,62 & 1,86 & 4,35 & - & 1,86 & 0,62 \\
\hline Toyota & 1,20 & 0,890 & 4,55 & - & 0,65 & - & - & - & 3,25 & 0,65 & 1,30 & 0,65 \\
\hline Hyundai & 0,75 & 0,843 & 5,21 & - & - & 2,08 & - & 1,04 & 5,21 & 1,04 & - & - \\
\hline Dacia & 0,70 & 0,789 & 3,33 & - & - & 2,22 & 1,11 & 1,11 & 5,56 & 1,11 & 3,33 & 2,22 \\
\hline Seat & 0,70 & 0,833 & 6,67 & - & - & 3,33 & 2,22 & 1,11 & 2,22 & 1,11 & - & - \\
\hline Chevrolet & 0,60 & 0,782 & 6,41 & 1,28 & 2,56 & 1,28 & - & 2,56 & 3,85 & 1,28 & - & 2,56 \\
\hline Volvo & 0,46 & 0,915 & 3,40 & - & - & - & - & - & 5,08 & - & - & - \\
\hline KIA & 0,34 & 0,837 & 9,3 & - & - & - & - & - & 6,98 & - & - & - \\
\hline Honda & 0,28 & 0,944 & 5,40 & - & - & - & - & - & 2,70 & - & - & - \\
\hline Mazda & 0,26 & 0,848 & 12,1 & - & - & - & - & - & 3,03 & - & - & - \\
\hline Mini & 0,22 & 0,793 & 17,2 & - & - & - & - & - & 3,45 & - & - & - \\
\hline Subaru & 0,16 & 0,714 & 14,3 & - & - & - & - & 14,3 & - & - & - & - \\
\hline Інші моделі & 0,84 & 0,738 & 17,8 & - & - & 2,80 & 0,93 & 1,87 & 3,74 & - & - & - \\
\hline Всього & 100 & 0,815 & 7,71 & 0,41 & 0,67 & 1,63 & 0,64 & 1,92 & 3,43 & 0,48 & 0,80 & 0,87 \\
\hline
\end{tabular}
зводимо у табл. 2.

Табл. 2. Відносні показники імпорту вживаних автомобілів і їх якості за 2016-2017 рр.

Найвищий рівень якості властивий переважно моделям німецьких виробників (Volkswagen, Mercedes-Benz, Audi, BMW) та іншим європейським і японським моделям (Skoda, Peugeot, Ford, Nissan, Toyota, Hyundai), прийнятий рівень якості яких перевищує 0,8 . Назагал виділяється порівняно високий рівень якості гальмівної системи автомобілів німецьких виробників - у середньому відносна кількість відмов становить 1,01\%, порівняно з 1,63 \% для всієї вибірки.

Як випливає із результатів сертифікаційних випробувань, найбільше невідповідностей виявлено в зовніш- ніх світлових приладах, гальмівній системі, двигуні та його системах та безпечному склі.

Зовнішні світлові прилади мають невідповідності нормативним вимогам - ДСТУ 3649:2010, Правила СЕК ООН №48.5. Переважно це пошкодження і тріщини на світловідбивальних поверхнях або розсіювачах світлотехнічних приладів, забруднена поверхня світлотехнічних приладів під час тонування і фарбування, що зменшує світлопропускання, змінює їхню силу світла, світлорозподіл або колір. Сигналізатори вмикання світлових приладів не роботоздатні або не мають передба- 
чених конструкцією символів. Промінь світла фар не відповідає європейському світлорозподілу. Кількість, колір чи режим роботи зовнішніх світлових приладів не відповідають вимогам нормативних документів. Зовнішні світлові прилади встановлені з відсутнім маркування знаком офіційного затвердження.

Загалом, щодо зовнішніх світлових приладів, то тут переважно виявляються невідповідності із фарами головного освітлення. Основні невідповідності виявляються через встановлення на автомобілі фар з американським світлорозподілом, замість європейського. 3'ясовано, що фари з європейським світлорозподілом у декілька разів дорожчі від фар з американським світлорозподілом. Через це покупці вживаних автомобілів надають перевагу дешевшій комплектації для зменшення їх вартості, що однак при вітчизняній сертифікації проявляється у невідповідності, яка усувається способом встановлення фар з європейським світлорозподілом.

Гальмівна система має невідповідності нормативним вимогам - Правила ЄЕК ООН №13.2 і ДСТУ 3649:2010. Переважно це наявність деталей системи 3 тріщинами, залишковою деформацією, відсутність герметичності чи непередбачений конструкцією контакт іiі трубопроводів 3 елементами кузова автомобіля. Рівень гальмівної рідини в резервуарі гідравлічного або пневмо-гідравлічного привода не відповідає вимогам. Система сигналізації та контролю гальмівної системи не функціонує згідно з вимогами. Антиблокувальні пристрої гальмівної системи та інші електронні пристрої підвищення стійкості руху автомобіля та їхні сигналізатори не функціонують згідно $з$ нормативними вимогами. Недостатня ефективність гальмівної системи та нерівномірність гальмівних зусиль на колесах однойменної осі.

У двигунів та їх систем спостерігаємо невідповідність нормативним вимогам - Правила ЄЕК ООН №49.2, Правила ЄЕК ООН № 83.3, ДСТУ 3649:2010. Зокрема це перевищення гранично допустимих норм викидів забруднювальних речовин. Перевищення рівня зовнішнього шуму. Підтікання палива, кришка паливного бака чи пристрої перекриття подавання палива нероботоздатні. Демонтовані системи нейтралізації відпрацьованих газів, окремих їх складових або нероботоз- датність їі сигналізатора. Прогари, механічні пробоїни, нещільності у з'єднаннях випускної системи автомобіля. Підтікання робочих рідин зі систем двигуна.

Щодо безпечного скла, то відсутнє маркування знаком офіційного затвердження (Правила ЄЕК ООН №43.2). Наявність сколів чи тріщин на вітровому склі у зоні дії склоочисників (ДСТУ 3649:2010 п.6.8.5 3). Світлопропускання скла менше від допустимої норми (надмірне тонування).

\section{Висновки:}

1. За статистичним аналізом результатів сертифікації, проведеної ДП НДІ "СИСТЕМА", досліджено модельний масив імпортованих вживаних легкових автомобілів за конкретними моделями і їх характерними відмовами.

2. Встановлено, що найбільш популярними в Україні (регіоні) є моделі легкових автомобілів фірми Renault i aвтомобільних фірм Німеччини.

3. Оцінено рівень якості імпортованих вживаних автомобілів, серед яких найвищий рівень якості властивий переважно моделям німецьких виробників (Volkswagen, Mercedes-Benz, Audi, BMW) та іншим європейським і японським моделям (Skoda, Peugeot, Ford, Nissan, Toyota, Hyundai), прийнятий рівень якості яких перевищує 0,8 .

4. Під час планування діяльності сервісних фірм (СТО) доцільно надати перевагу технічному обслуговуванню автомобілів фірм Renault, Volkswagen, Opel, MercedesBenz, Skoda, Peugeot, Ford, Citroen.

\section{Перелік використаних джерел}

Import. (2017). Import maszyn w Urainu zris udwitsi. Retrieved from: https://www.epravda.com.ua/news /2017/11/21/631392/. [In Ukrainian].

Sertyficat. (2015). Sertyficaciya UkrSEPRO. Retrieved from: https//ukrsepro.dp.ua/index.php/certification. [In Russian].

Sredstwa. (2016). Sertyficaciya avtomobilej i transportnych sredstw. Friedman. Retrieved from: https:/www.com.ua/info/tariff-regulation/certifications/certificacija-transportnyh-sredstv-419/. Russian].

Yakovenco, Y. V., \& Krajnyc, L. V. (2005). Conzepciya formuwannja rozwytcu avtomobilnoji promyslovosti Ukrainy na period do 2010-2015 r. r. Awtotechnica. Awtobusy, wantazivky, 2, 14-22. [In Ukrainian].

С. В. Немый, Я. С. Ярошинский
Начиональный университет "Львовская политехника", г. Львов, Украина

\section{ПРОБЛЕМЫ КАЧЕСТВА ИМПОРТИРОВАННЫХ БЫВШИХ В УПОТРЕБЛЕНИИ АВТОМОБИЛЕЙ В АСПЕКТЕ БЕЗОПАСНОСТИ ЭКСПЛУАТАЦИИ}

Проведена количественная оценка модельного массива и качества импортированных автомобилей, бывших в эксплуатации. Результаты исследований будут информационной базой для: определения наиболее и наименее популярных в Украине (регионе) моделей; уровня качества определенных моделей импортированных автомобилей; ориентирования сервисных служб (СТО) для освоения технологии технического обслуживания и ремонта автомобилей, исходя из количества наиболее распространенных в Украине моделей импортированных легковых автомобилей, бывших в эксплуатации. По статистическому анализу результатов сертификации, проведенной ГП НИИ "СИСТЕМА", исследован модельный массив импортированных легковых автомобилей, бывших в эксплуатации, по моделям и их характерным дефектам. Установлено, что наиболее популярными в Украине являются модели легковых автомобилей фирмы Renault и автомобильных фирм Германии. Оценен уровень качества импортированных автомобилей, бывших в эксплуатации, среди которых наивысший уровень качества свойственный преимущественно моделям немецких производителей (Volkswagen, Mercedes-Benz, Audi, BMW) и другим европейским и японским моделям (Skoda, Peugeot, Ford, Nissan, Toyota, Hyundai), принятый уровень качества которых превышает 0,8. В общем выделен сравнительно высокий уровень качества тормозной системы автомобилей немецких производителей - в среднем относительное количество дефектов составляет $1,01 \%$, в сравнении с 1,63 \% для всей выборки. При планировании деятельности сервисных фирм (СТО) целесообразно предоставить преимущество техническому обслуживанию автомобилей фирм Renault, Volkswagen, Opel, Mercedes-Benz, Skoda, Peugeot, Ford, Citroen.

Ключевые слова: стандартизация; качество; сертификация; ГП НИИ "СИСТЕМА"; несоответствия; автомобили; импорт автомобилей. 
S. V. Niemyi, Ya. S. Yaroshynskyi

Lviv Polytechnic National University, Lviv, Ukraine

THE PROBLEMS OF QUALITY OF IMPORTED USED CARS IN TERMS OF SAFETY OF OPERATION

The technical condition of imported used cars due to operational wear is sometimes not in accordance with the factorymanufacturer and relevant regulatory documents (national standards) regarding the safety of operation. The technical condition of imported used cars due to operational wear and tear sometimes doesn't correspond to the factory-manufacturer's indicators and relevant regulatory documents (national standards) regarding the safety of operation. This case requires the effective functioning of the national certification system in order to prevent the use of cars with defects of aggregates and systems that affect traffic safety and ecological safety, on what safety of life of citizens of country depends. Therefore, the purpose of the study is to quantify the model array and the quality of imported used cars. Research results are to be an information base for determining the following: the most and the least popular in Ukraine (region) models; the quality level of certain models of imported cars; the orientation of service firms (SRT) for the development of technology of maintenance and repair of cars based on the volume of the most common models of imported used cars in Ukraine. The authors have obtained the following results. Firstly, the statistical analysis of the results of certification carried out by SYSTEM SE SRI investigated the model array of imported used cars by models and their characteristic failures. Secondly, the most popular in Ukraine are models of passenger cars of the company Renault and automobile firms of Germany. Thirdly, the evaluation of the quality of imported used cars, among which the highest level of quality is inherent mainly to models of German manufacturers (Volkswagen, Mercedes-Benz, Audi, BMW) and other European and Japanese models (Skoda, Peugeot, Ford, Nissan, Toyota, Hyundai), which quality level exceeds 0.8 . All in all, a relatively high level of quality of the braking system of cars of German manufacturers, with an average relative number of failures $1.01 \%$, compared with $1.63 \%$ for the entire sample, is impressive. Finally, when planning the activities of service firms (SRT) it is advisable to give preference to the technical maintenance of the cars of such companies as Renault, Volkswagen, Opel, Mercedes-Benz, Skoda, Peugeot, Ford, Citroen.

Keywords: standardization; quality; certification; SISTEMA state enterprise; inconsistencies; used cars; import of automobiles. 